\title{
UPAYA MENINGKATKAN KETERAMPILAN DAN AKURASI SHOOTING BOLABASKET MENGGUNAKAN METODE DRILL PADA PESERTA EKSTRAKURIKULER BOLABASKET PUTRA SMP
}

\author{
Irfan Zidny Alfiansyah ${ }^{1}$, Oni Bagus Januarto ${ }^{2}$
}

Universitas Negeri Malang, Jalan Semarang 5 Malang

\begin{abstract}
Info Artikel
Sejarah Artikel:

Diterima Desember 2017

Disetujui April 2018

Dipublikasikan Agustus 2018

\section{Keywords:}

Shooting, Bolabasket, Metode Drill.

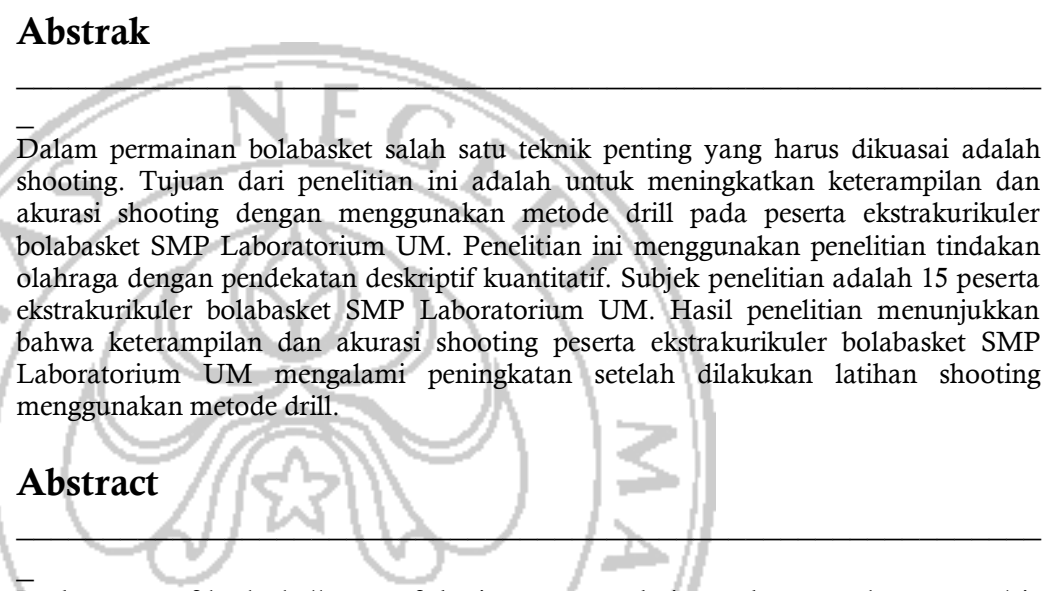

In the game of basketball, one of the important techniques that must be mastered is shooting. The purpose of this research is to improve the skills and shooting accuracy by using the methods of drill in basketball extracurricular at SMP Laboratorium Universitas Negeri Malang. This research used Sport Action Research as the design with descriptive quantitative approaches. The subjects were 15 basketball extracurricular participants of SMP Laboratorium UM. The results showed that the technique and shooting skill of basketball athletes at SMP Laboratorium Universitas Negeri Malang increased after the shooting exercises through drill method.
\end{abstract}

\section{PENDAHULUAN}

Ekstrakurikuler menurut Menteri Pendidikan dan Kebudayaan RI Nomor 62 tahun 2014 (2014:2) menjelaskan "bahwa ekstrakurikuler adalah kegiatan pendidikan yang dilakukan oleh peserta didik diluar jam belajar dan dilakukan dibawah bimbingan sekolah dengan tujuan untuk mengembangkan bakat, minat, kepribadian, serta kemampuan peserta didik yang lebih luas". Menurut Hapsari, dkk (2010:1) menjelaskan "Ekstrakurikuler merupakan salah satu aktivitas positif yang dilakukan remaja untuk mengisi waktu luang". "Tujuan keseluruhan dari olahraga di sekolah adalah membangkitkan minat dan meletakkan 
dasar bagi prestasi anak dalam olahraga dimasyarakat, di luar sekolah baik langsung maupun untuk masa yang akan datang" (Susana \& Wibowo, 2013:139).

Dari beberapa pengertian di atas dapat disimpulkan bahwa ekstrakurikuler adalah suatu kegiatan yang dilakukan diluar jam pelajaran sebagai salah satu aktivitas positif dengan tujuan untuk mengembangkan bakat, minat, kepribadian, serta kemampuan peserta didik, selain itu juga dapat untuk mengisi waktu luang. Kegiatan ekstrakurikuler dilaksanakan sesuai dengan kebijakan sekolah masing-masing. Ada yang dilakukan disore hari ada pula yang dilakukan dipagi hari selagi tidak meggamggu kegiatan pembelajaran di sekolah tersebut. Selain itu, kegiatan ekstrakurikuler yang berprestasi dapat meningkatkan kualitas dan mutu dari sekolah tersebut dimata masyarakat luas. Prestasi yang diperoleh siswa juga dapat menjadikan semangat siswa tersebut untuk menempuh pendidikan yang lebih baik di tempat mereka belajar. Kegiatan ekstrakurikuler mempunyai peran penting dalam mengembangkan bakat dan minat anak di sekolah untuk mendapatkan prestasi dibidang olahraga maupun yang lainnya.

Olahraga menurut Setiadji dalam Mu'arifin (2012:19) adalah "latihan dari semua aktivitas fisik yang dilakukan di luar sekolah dan timbul karena kesenangan, keinginan berlebih, dan memperbaiki prestasi, keinginan dalam permainan, serta adanya unsur persaingan". Olahraga selain dapat menyehatkan jasmani juga dapat mempertahankan kebugaran tubuh. Olahraga yang paling banyak digemari adalah olahraga yang berbentuk permainan, karena olahraga yang berbentuk permainan akan menimbulkan efek senang pada orang yang melakukan. Salah satu olahraga yang digemari banyak orang mulai dari orang dewasa sampai dengan anak-anak adalah bolabasket.

Menurut FIBA (2014:7) "bolabasket dimainkan oleh dua regu, setiap regu terdiri dari lima pemain yang saling memasukkan bola ke keranjang lawan untuk mencetak angka. Ahmadi (2007:2) mengatakan bahwa bolabasket adalah "permainan yang sederhana". Sedangkan menurut Oliver (2007:vi-viii) “ Bolabasket adalah olahraga menyenangkan, kompetitif, mendidik, menghibur, dan menyehatkan. Setiap pertandingan dibagi 4 quarter yang masing-masing berlangsung selama 8 hingga 12 menit. Tujuan permainan bolabasket ini adalah memasukan bola ke dalam keranjang yang tingginya 3,05 meter, regu yang paling banyak memasukan bola adalah regu yang menang ".
Dari pernyataan-pernyataan tersebut dapat disimpulkan bahwa olahraga bolabasket adalah olahraga yang menyenangkan, kompetitif, mendidik, menghibur, dan menyehatkan yang dimainkan oleh 10 orang, terbagi atas 2 regu, tiap-tiap regu berusaha memasukkan bola ke dalam keranjang yang dijaga regu lawan dan berusaha menjaga keranjang sendiri serta regu yang memperoleh poin terbanyak sebagai pemenangnya.

Bolabasket merupakan olahraga yang dianggap unik karena diciptakan secara tidak sengaja oleh seorang pastor. Pada 15 Desember 1891, Dr. James Naismith, seorang pastor asal Kanada yang mengajar sebuah fakultas untuk para mahasiswa profesional di YMCA (Young Man's Christian Assocation) di Springfield, Massachusetts. Dr. James Naismith harus membuat suatu permainan di ruang tertutup untuk mengisi waktu para siswa pada masa liburan musim dingin di New England. Naismith terinspirasi dari permainannya pada saat kecil di Ontario, dan permainan tersebut sekarang dikenal dengan bolabasket. (James Naismith:Wikipedia).

Menurut Wissel (2000:15) "olahraga bolabasket adalah olahraga yang unik karena bukan merupakan permainan tim saja, tetapi juga permainan individual". Menurut Sukma, dkk (2013:4) menyatakan "permainan bolabasket merupakan olahraga yang sangat digemari saat ini, dan merupakan aktivitas yang cukup menarik perhatian banyak orang, baik sebagai pengisi waktu luang maupun ajang kompetisi". Jadi menurut pendapat saya olahraga bolabasket adalah permainan yang dimainkan oleh 2 regu masing-masing 5 orang pemain, bertujuan untuk memasukkan bola ke keranjang lawan. Dan olahraga ini sangat digemari baik untuk mengisi waktu luang maupun untuk mendapatkan prestasi.

Dalam olahraga bolabasket banyak teknik dasar yang harus dikuasai, seperti dribbling, passing, shooting, pivot, dan rebound. Semua teknik dasar tersebut harus bisa dikuasai dengan baik agar dapat melakukan permainan bolabasket dengan baik secara individual, kemudian digabungkan dengan koordinasi tim seperti strategi defense maupun offense untuk menciptakan permainan yang baik dalam tim. Teknik dasar shooting adalah salah satu teknik dasar yang sangat penting dalam permainan bolabasket. Karena teknik dasar shooting digunakan untuk mencetak angka. Menurut Wissel (2000:43) "shooting merupakan keahlian yang sangat penting dalam olahraga bolabasket". Sedangkan menurut Kurniawan (2014:250) "Teknik yang sangat dominan dalam 
permainan bolabasket yaitu teknik menembak atau shooting karena kemenangan suatu tim bolabasket diukur melalui pengumpulan angka atau poin terbanyak". Jadi dari beberapa penjelasan di atas, shooting merupakan salah satu teknik dasar yang paling penting. Teknik dasar seperti passing, dribbling, rebounding mungkin mengantarkan anda memperoleh peluang besar untuk membuat skor, tetapi tetap saja anda harus dapat melakukan shooting. Sebetulnya, teknik dasar shooting dapat menutupi kelemahan teknik dasar lainnya.

Salah satu teknik dalam permainan bolabasket adalah melakukan tembakan ke dalam ring (shooting), dan dalam melakukan shooting diperlukan akurasi yang baik dalam setiap tembakan. Menurut Ahmadi (2007:34) "menembak (shooting) merupakan salah satu kegiatan yang harus dilakukan dalam permainan bolabasket". Sedangkan menurut Amber (dalam Erwin, 2013) menyatakan "Shooting merupakan suatu keterampilan yang paling penting. Untuk memiliki ketrampilan ini, dibutuhkan latihan-latihan yang banyak sekali". Podmenik, dkk juga mengatakan bahwa "The shot at the basket is one of the elements that significantly influences performance in basketball", yang artinya shooting atau tembakan kearah ring adalah salah satu elemen penting yang mempengaruhi Penampilan dalam olahraga bolabasket.

Jadi untuk melakukan shooting pemain harus melatih keterampilan teknik dasar shooting untuk meningkatkan akurasinya. Menurut Kamus Besar Bahasa Indonesia yang dikutip dalam jurnal Setiawan (2016:276) "Akurasi adalah tepat, benar, atau ketepatan". Menurut Harmono (2014:52) "Ketepatan adalah kemampuan seorang untuk menggerakkan suatu gerak kesuatu sasaran sesuai dengan tujuan".

Jadi dari beberapa pendapat di atas, dapat disimpulkan bahwa akurasi adalah kemampuan seseorang dalam melakukan suatu gerak atau keterampilan tertentu sesuai dengan tujuan atau sasaran. Menurut Podmenik dkk (2012) "Shooting accuracy is of great importance. The shooting technique differs according to the distance from the basket and depends, to some extent, on the player's body height and playing position", yang artinya akurasi shooting sangat penting. Teknik shooting/menembak berbedabeda sesuai dengan jarak dari ring basket, sampai batas tertentu, pada ketinggian pemain dan posisi bermain.

Zhen dkk (2013) mengatakan "Basketball is a sport that scores determines its results, and shooting skill determines score percentage which means shooting skill determines the result of a basketball game to some extent", yang artinya bolabasket adalah olahraga yang hasilnya ditentukan oleh skor, dan keterampilan shooting menentukan persentase skor yang berarti keterampilan shooting dapat menentukan hasil pertandingan bolabasket sampai batas waktu tertentu. Permainan bolabasket adalah permainan yang dimainkan oleh dua regu putra atau putri yang masing-masing regu terdiri atas 5 orang pemain di lapangan dan 7 orang pemain di bangku cadangan. Populasi permainan ini sangat bagus, baik itu di dalam maupun di luar negeri. Sehingga cabang olahraga tersebut disetiap event resmi baik ditingkat nasional ataupun internasional selalu dipertandingkan.

Bolabasket sudah mulai berkembang di Indonesia pada masa revolusi kemerdekaan tahun 1948. Pada tahun itu juga di selenggarakan PON (Pekan Olahraga Nasional) untuk yang pertama kalinya. Salah satu cabang olahraga yang dipertandingkan pada PON tahun 1948 adalah bolabasket. Hal ini membuktikan bahwa olahraga bolabasket telah memasyarakat dan secara resmi diakui oleh negara. Kemudian pada tahun 1955 disepakati pembentukan Persatuan Bolabasket Seluruh Indonesia yang disingkat dengan PERBASI.

Semakin berkembangnya dunia bolabasket di Indonesia para pelatih sebagai salah satu komponen penting yang ada di dalamnya, serta perlu dipersiapkan dengan lebih baik, sehingga pada akhirnya dapat berperan besar terutama dalam proses pembinaan pemain yang akan berdampak langsung pada pencapaian prestasi bolabasket. Menguasai teknik dasar bolabasket merupakan kunci sukses untuk menampilkan permainan yang maksimal disamping memiliki kondisi fisik, taktik, dan mental yang baik.

Menurut Budiwanto (2012:16) latihan adalah "proses melakukan kegiatan olahraga yang dilakukan berdasarkan program latihan yang disusun secara sistematis bertujuan untuk meningkatkan kemampuan atlet dalam upaya mencapai prestasi semaksimal mungkin, terutama dilaksanakan untuk persiapan menghadapi suatu pertandingan". Menurut Ahmadi (2007:33) mengatakan "teori mengenai latihan pendahuluan yang harus dilakukan, antara lain 1) setiap pemain harus dapat menunjukkan puncak kondisi fisiknya, 2) kondisi fisik dicapai melalui basic drill dan latihan-latihan bertanding". Menurut Harsono (2015:50) training adalah "proses yang sistematis dari berlatih atau bekerja yang dilakukan secara berulang-ulang dengan kian 
hari kian menambah beban latihan atau pekerjaannya".

Dari pendapat beberapa ahli tentang latihan di atas, maka dapat ditarik kesimpulan bahwa latihan adalah suatu kegiatan yang dilakukan secara sadar dan berdasarkan program latihan yang disusun secara sistematis dengan tujuan untuk meningkatkan kemapuan atau keterampilan atlet.

Menurut Harsono (2015:39) "tujuan dari latihan atau training adalah membantu atlet untuk meningkatkan keterampilan dan prestasinya semaksimal mungkin". "Sport training aims at achieving high performace in sport competition" (Umashankara dkk 2014:453) maksudnya latihan olahraga bertujuan untuk mencapai hasil tinggi dalam kompetisi olahraga. Dari beberapa pendapat ahli di atas maka tujuan latihan adalah untuk meningkatkan kemampuan seorang atlet sehingga dapat memperoleh prestasi yang diharapkan.

Untuk mencapai prestasi yang maksimal sebelum latihan dilaksanakan sebaiknya pelatih menyusun atau memiliki program latihan. Dalam penerapan program latihan sebaiknya memperhatikan dasar-dasar dalam latihan. Menurut Harsono (2015:51) berikut ini adalah "dasar-dasar latihan yang sebaiknya di terapkan dalam program latihan". Karena tanpa mengetahui prinsip-prinsip dan tujuan latihan tak mungkin atlet berlatih dan dilatih dengan sukses. Prinsip-prinsip tersebut menurut (Harsono 2015:37-89) adalah : (a) Prinsip Beban Lebih (Overload Principle) adalah prinsip latihan yang menekankan pada pembebanan latihan yang lebih berat daripada yang mampu dilakukan oleh atlet. (b) Penambahan beban. adalah prinsip latihan dengan meningkatkan beban latihan secara bertahap dan ajeg, sehingga dapat meningkatkan prestasi seorang atlet. (c) Menghindari latihan berlebih / Overtraining. Latihan yang dilakukan secara berlebihan akan dapat mengakibatkan penurunan penampilan atlet. (d) Prinsip perkembangan menyeluruh. Melakukan atau terlibat dalam semua kegiatan sebelum mengambil satu spesialisasi keteramplan tertentu. (e) Perlibatan dalam beragam aktivitas. Tidak membatasi atlet untuk melakukan aktivitas olahraga lainnya. Hal ini dimaksudkan agar atlet mendapatkan tantangan pada tubuhnya. (f) Prinsip Interdependensi. Berbagai unsur lambat laun akan saling berkaitan antara seluruh organ dan sistem manusia, serta antara sistem fisiologis dan psikologis. (g) Prinsip spesialisasi. Spesialisasi berarti mencurahkan segala kemampuan, baik fisik maupun psikis pada suatu cabang olahraga tertentu. (h) Prinsip Individualisasi.

Latihan harus sesuai dengan tingkat kemampuan seseorang. Seluruh program latihan harus direncanakan dengan kondisi fisiologis dan psikologis. (i) Prinsip variasi. Untuk mencegah kemungkinan timbulnya kebosanan berlatih, pelatih harus kreatif dalam membuat variasi-variasi latihan. (j) Prinsip kembali asal (reversibility). Jika latihan tidak dilakukan secara berkesinambungan atau ada jeda latihan yang cukup lama kondisi fisik atau tubuh akan kembali kekeadaan semula. (k) Prinsip Pemulihan (recovery). Dalam sebuah program latihan harus memberikan waktu pemulihan atau istiahat yang cukup, karena jika tidak atlet akan mengalami kelelahan/overload.

Hasil observasi awal hari pertama yang dilakukan pada peserta putra ekstrakurikuler bolabasket SMP Laboratorium UM, diperoleh data sebagai berikut: dari 15 peserta yang hadir (1) $80 \%$ peserta dapat melakukan teknik dribble dengan cukup baik, dan $20 \%$ peserta yang belum menguasai teknik dribble dengan baik. (2) $86,67 \%$ peserta dapat melakukan teknik passing dengan cukup baik, dan 13,33\% peserta yang belum menguasai teknik passing dengan baik. (3) $73,33 \%$ peserta dapat melakukan teknik shooting dengan cukup baik, dan $26,67 \%$ peserta yang belum menguasai teknik shooting dengan baik. (4) $86,67 \%$ peserta dapat melakukan teknik pivot dengan cukup baik, dan $13,33 \%$ peserta yang belum menguasai teknik pivot dengan baik.

Selanjutnya pada hari kedua peneliti mengamati penggunakan teknik dasar bolabasket pada permainan 3 on 3. (1) Dalam game tersebut dari 74 total dribble yang dilakukan, 56,75\% dilakukan dengan benar, dan $43,25 \%$ dilakukan dengan salah. (2) Selanjutnya dari 100 total passing yang dilakukan, $71,29 \%$ dilakukan dengan benar, dan 28,71\% dilakukan dengan salah. (3) Selanjutnya dari 53 total shooting yang dilakukan, 39,63\% dilakukan dengan benar, dan 60,37\% dilakukan dengan salah. (4) Selanjutnya dari 46 total pivot yang dilakukan, 78,26\% dilakukan dengan benar, dan $21,74 \%$ dilakukan dengan salah. (5) Selanjutnya dari 35 total rebound yang dilakukan, 62,86\% dilakukan dengan benar, dan 37,14\% dilakukan dengan salah.

Selanjutnya pada hari ketiga peneliti mengamati penggunakan teknik dasar bolabasket pada permainan bolabasket. (1) Dalam game tersebut dari 74 total dribble yang dilakukan, 59,46\% dilakukan dengan benar, dan 40,54\% dilakukan dengan salah. (2) Selanjutnya dari 127 total passing yang dilakukan, 72,44\% dilakukan dengan benar, dan 27,56\% dilakukan 
dengan salah. (3) Selanjutnya dari 61 total shooting yang dilakukan, 33,33\% dilakukan dengan benar, dan $66,67 \%$ dilakukan dengan salah. (4) Selanjutnya dari 44 total pivot yang dilakukan, 79,55\% dilakukan dengan benar, dan 20,45\% dilakukan dengan salah. (5) Selanjutnya dari 63 total rebound yang dilakukan, 68,25\% dilakukan dengan benar, dan $31,75 \%$ dilakukan dengan salah.

Berdasarkan observasi awal yang dilakukan oleh peneliti di SMP Laboratorium UM, peneliti menemukan masalah pada akurasi shooting peserta ekstrakurikuler bolabasket putra SMP Laboratorium UM. Untuk memperkuat hal tersebut peneliti menyebarkan angket kepada 20 peserta ekstrakurikuler dan pelatih bolabasket SMP Laboratorium UM, selain itu juga melakukan wawancara dengan beberapa peserta ekstrakurikuler. Hasilnya diketahui bahwa $57,15 \%$ peserta ekstrakurikuler memahami konsep tentang teknik dasar shooting bolabasket, tetapi $70 \%$ peserta ekstrakurikuler masih kesulitan dalam mempraktikkan teknik tersebut.

Berdasarkan wawancara dengan pelatih, pelatih memberikan keterangan bahwa pemain masih kurang dalam hal teknik dasar khususnya shooting. Dan pelatih juga menjelaskan bahwa pada setiap pertandingan yang telah dilakukan jumlah percobaan shooting dan skor yang dihasilkan sering tidak seimbang.

Untuk meningkatkan akurasi shooting peserta ekstrakurikuler bolabasket SMP Laboratoriun UM, peneliti menggunakan metode drill. Menurut Sagala (2009:217) metode latihan drill atau metode training "merupakan suatu cara mengajar yang baik untuk menanamkan kebiasaan-kebiasaan tertentu. Juga sebagai sarana untuk memperoleh suatu ketangkasan, ketepatan, kesempatan, dan keterampilan. Alasan peneliti menggunakan metode drill karena pembentukan kebiasaan menggunakan metode ini akan menambah ketepatan dan kecepatan dalam pelaksanaannya, dan gerakan-gerakan yang rumit, kompleks akan menjadi otomatis.

Latihan atau pembelajaran menggunakan metode drill dapat meningkatkan keterampilan olahraga secara signifikan. (Fikri 2013; Candra, 2014; Mahardika, 2014). Tujuan dalam penelitian ini adalah keterampilan dan akurasi shooting peserta ekstrakurikuler bolabasket SMP Laboratorium Universitas Negeri Malang akan meningkat setelah diberikan latihan menggunakan metode drill.

\section{METODE}

Berdasarkan tujuannya penelitian ini menggunakan rancangan penelitian tindakan olahraga (PTO). Dan penelitian tindakan olahraga memiliki kesamaan dengan penelitian tindakan kelas (PTK). Menurut Trianto (2011:13) penelitian tindakan kelas adalah "penelitian yang dilakukan pada sebuah kelas untuk mengetahui akibat tindakan yang diterapkan pada suatu subjek penelitian".

Kehadiran peneliti dalam penelitian ini adalah sebagai rekan kerja bagi pelatih ekstrakurikuler bolabasket, yaitu saling bekerjasama atau berkolaborasi dalam menyusun konsep tindakan yang akan dilakukan. Peran peneliti dalam penelitian ini sebagai pengamat (observer), pelatih ekstrakurikuler bolabasket sebagai pelatih bolabasket. Peneliti dan Pelatih terlibat langsung dalam merencanakan tindakan, melakukan tindakan, observasi, refleksi, pengumpulan data, dan menganalisis data.

Penelitian tindakan olahraga ini dilaksanakan di ekstrakurikuler bolabasket SMP Laboratorium UM, alamat J1. Simpang Bogor No. T 7, Sumbersari, Kec. Lowokwaru, Kota Malang, Jawa Timur. Subjek coba dalam penelitian adalah para peserta ekstrakurikuler sepakbola SMP Laboratorium UM yang berjumlah 15 peserta laki-laki. Peserta kegiatan ekstrakurikuler. Data diperoleh pada saat proses latihan. Sedangkan sumber data dari penelitian ini diperoleh dari peserta ekstrakurikuler bolabasket putra SMP Laboratorium UM yang berjumlah 15 pemain. Pengumpulan data dilakukan dengan menggunakan Observasi, dokumentasi, catatan lapangan, dan tes. Proses pelaksanaan penelitian tindakan olahraga (PTO) bersifat kolaboratif partisipan dengan pelatih ekstrakurikuler bolabasket. Penelitian ini dilakukan dalam dua siklus, masing-masing kegiatan utama yang ada pada setiap siklus yaitu: (1) Perencanaan, (2) Pelaksanaan, (3) Pengamatan, (4) refleksi.

\section{HASIL}

Pada pertemuan ke-1 siklus I yang dilaksanakan pada hari Selasa tanggal 7 Maret 2017 pukul 15.00-17.00. Pelatih memberikan beberapa drill variasi latihan shooting yaitu: (1) Titan shooting drill, (2) Elbow catch and shooting drill, (3) 3 way shooting drill. Hasilnya adalah pada sikap persipan persentase benar peserta dari observer 1 sebanyak 40\%, sedangkan dari observer 2 sebanyak 43,33\%. Gerakan shooting 
didapatkan hasil persentase benar peserta dari observer 1 sebanyak 31,11\%, sedangkan dari observer 2 sebanyak 35,56\%. Pada gerakan lanjutan didapatkan hasil persentase benar peserta dari observer 1 sebanyak $26,67 \%$, sedangkan dari observer 2 sebanyak 26,67\%.

Pada pertemuan ke-2 siklus I yang dilaksanakan pada hari Jum'at tanggal 10 Maret 2017 pukul 15.00-17.00. Pelatih memberikan beberapa drill variasi latihan shooting yaitu: (1) Elbow catch and shooting drill, (2) 3 way shooting drill, (3) Post shooting drill. Hasilnya adalah pada sikap persiapan didapatkan hasil persentase benar peserta dari observer 1 sebanyak 33,33\%\%, sedangkan dari observer 2 sebanyak 33,33\%. Gerakan shooting didapatkan hasil persentase benar peserta dari observer 1 sebanyak 28,89\%, sedangkan dari observer 2 sebanyak 26,67\%. Pada gerakan lanjutan didapatkan hasil persentase benar peserta dari observer 1 sebanyak 23,33\%, sedangkan dari observer 2 sebanyak 23,33\%.

Pada pertemuan ke-3 siklus I yang dilaksanakan pada hari Selasa tanggal 14 Maret 2017 pukul 15.00-17.00. Pelatih memberikan beberapa drill variasi latihan shooting yaitu: (1) 3 way shooting drill, (2) Post shooting drill, (3) free throw line shooting. Hasilnya adalah pada sikap persiapan didapatkan hasil persentase benar peserta dari observer 1 sebanyak $50 \% \%$, sedangkan dari observer 2 sebanyak 46,67\%. Gerakan shooting didapatkan hasil persentase benar peserta dari observer 1 sebanyak $31,11 \%$, sedangkan dari observer 2 sebanyak $31,11 \%$. Pada gerakan lanjutan didapatkan hasil persentase benar peserta dari observer 1 sebanyak $36,67 \%$, sedangkan dari observer 2 sebanyak 33,33\%.

Pada pertemuan ke- 4 siklus I yang dilaksanakan pada hari Jum'at tanggal 17 Maret 2017 pukul 15.00-17.00. Pelatih memberikan beberapa drill variasi latihan shooting yaitu: (1) Titan shooting drill, (2) Elbow catch and shooting drill, (3) Post shooting drill. Hasilnya adalah pada sikap persiapan didapatkan hasil persentase benar peserta dari observer 1 sebanyak 43,33\%, sedangkan dari observer 2 sebanyak $66,67 \%$. Gerakan shooting didapatkan hasil persentase benar peserta dari observer 1 sebanyak 24,44\%, sedangkan dari observer 2 sebanyak 37,78\%. Pada gerakan lanjutan didapatkan hasil persentase benar peserta dari observer 1 sebanyak 30\%, sedangkan dari observer 2 sebanyak 43,33\%.

Pada pertemuan ke-5 siklus I yang dilaksanakan pada hari Selasa tanggal 21 Maret 2017 pukul 15.00-17.00. Pelatih memberikan beberapa drill variasi latihan shooting yaitu: (1) Elbow catch and shooting drill, (2) 3 way shooting drill, (3) free throw line shooting. Hasilnya adalah pada sikap persiapan didapatkan hasil persentase benar peserta dari observer 1 sebanyak $66,67 \%$, sedangkan dari observer 2 sebanyak $63,33 \%$. Gerakan shooting didapatkan hasil persentase benar peserta dari observer 1 sebanyak $37,78 \%$, sedangkan dari observer 2 sebanyak $37,78 \%$. Pada gerakan lanjutan didapatkan hasil persentase benar peserta dari observer 1 sebanyak $43,33 \%$, sedangkan dari observer 2 sebanyak $40 \%$.

Pada pertemuan ke-6 siklus I yang dilaksanakan pada hari Jum'at tanggal 24 Maret 2017 pukul 15.00-17.00. Pelatih memberikan beberapa drill variasi latihan shooting yaitu: (1) Titan shooting drill, (2) Post shooting drill, (3) free throw line shooting. Hasilnya adalah pada sikap persiapan didapatkan hasil persentase benar peserta dari observer 1 sebanyak 63,33\%, sedangkan dari observer 2 sebanyak 57,67\%. Gerakan shooting didapatkan hasil persentase benar peserta dari observer 1 sebanyak 44,44\%, sedangkan dari observer 2 sebanyak 40\%. Pada gerakan lanjutan didapatkan hasil persentase benar peserta dari observer 1 sebanyak 46,67\%, sedangkan dari observer 2 sebanyak 50\%.

Persentase rata-rata peningkatan akurasi shooting peserta ekstrakurikuler bolabasket SMP Laboratorium UM sebelum diberikan perlakuan dan sesudah siklus I sebesar 25,43\%. Berdasarkan evaluasi dan refleksi pada siklus I ada peningkatan keterampilan dan akurasi shooting bolabasket pada peserta ekstrakurikuler di SMP Laboratorium UM, akan tetapi belum terlihat signifikan, maka perlu diadakan peningkatan keterampilan dan akurasi shooting menggunakan metode drill pada siklus II.

Pada pertemuan ke-1 siklus II yang dilaksanakan pada hari Selasa tanggal 4 April 2017 pukul 15.00-17.00. Pelatih memberikan beberapa drill variasi latihan shooting yaitu: (1) Titan shooting drill, (2) Elbow catch and shooting drill, (3) 3 way shooting drill. Hasilnya adalah pada sikap persiapan didapatkan hasil persentase benar peserta dari observer 1 sebanyak 53,33\%, sedangkan dari observer 2 sebanyak 53,33\%. Gerakan shooting didapatkan hasil persentase benar peserta dari observer 1 sebanyak 37,78\%, sedangkan dari observer 2 sebanyak 33,33\%. Pada gerakan lanjutan didapatkan hasil persentase benar peserta dari observer 1 sebanyak 43,33\%, sedangkan dari observer 2 sebanyak $40 \%$.

Pada pertemuan ke-2 siklus II yang dilaksanakan pada hari Jum'at tanggal 7 April 2017 pukul 15.00-17.00. Pelatih memberikan beberapa drill variasi latihan shooting yaitu: (1) Elbow catch and shooting drill, (2) 3 way shooting drill, (3) Post shooting drill. Hasilnya adalah pada sikap persiapan didapatkan hasil persentase benar peserta dari observer 1 sebanyak $80 \%$, sedangkan dari observer 2 sebanyak $80 \%$. 
Gerakan shooting didapatkan hasil persentase benar peserta dari observer 1 sebanyak 53,33\%, sedangkan dari observer 2 sebanyak $55,55 \%$. Pada gerakan lanjutan didapatkan hasil persentase benar peserta dari observer 1 sebanyak 43,33\%, sedangkan dari observer 2 sebanyak 46,67\%.

Pada pertemuan ke-3 siklus II yang dilaksanakan pada hari Selasa tanggal 11 April 2017 pukul 15.00-17.00. Pelatih memberikan beberapa drill variasi latihan shooting yaitu: (1) 3 way shooting drill, (2) Post shooting drill, (3) free throw line shooting. Hasilnya adalah pada sikap persiapan didapatkan hasil persentase benar peserta dari observer 1 sebanyak 83,33\%, sedangkan dari observer 2 sebanyak 83,33\%. Gerakan shooting didapatkan hasil persentase benar peserta dari observer 1 sebanyak 66,67\%, sedangkan dari observer 2 sebanyak $62,22 \%$. Pada gerakan lanjutan didapatkan hasil persentase benar peserta dari observer 1 sebanyak 53,33\%, sedangkan dari observer 2 sebanyak $53,33 \%$.

Pada pertemuan ke-4 siklus II yang dilaksanakan pada hari Sabtu tanggal 15 April 2017 pukul 15.00-17.00. Pelatih memberikan beberapa drill variasi latihan shooting yaitu: (1) Titan shooting drill, (2) Elbow catch and shooting drill, (3) Post shooting drill. Hasilnya adalah pada sikap persiapan didapatkan hasil persentase benar peserta dari observer 1 sebanyak $80 \%$, sedangkan dari observer 2 sebanyak $83,33 \%$. Gerakan shooting didapatkan hasil persentase benar peserta dari observer 1 sebanyak $64,44 \%$, sedangkan dari observer 2 sebanyak $62,22 \%$. Pada gerakan lanjutan didapatkan hasil persentase benar peserta dari observer 1 sebanyak $50 \%$, sedangkan dari observer 2 sebanyak $50 \%$.

Pada pertemuan ke-5 siklus II yang dilaksanakan pada hari Selasa tanggal 25 April 2017 pukul 15.00-17.00. Pelatih memberikan beberapa drill variasi latihan shooting yaitu: (1) Elbow catch and shooting drill, (2) 3 way shooting drill, (3) free throw line shooting. Hasilnya adalah pada sikap persiapan didapatkan hasil persentase benar peserta dari observer 1 sebanyak $90 \%$, sedangkan dari observer 2 sebanyak $90 \%$. Gerakan shooting didapatkan hasil persentase benar peserta dari observer 1 sebanyak 73,33\%, sedangkan dari observer 2 sebanyak $68,89 \%$. Pada gerakan lanjutan didapatkan hasil persentase benar peserta dari observer 1 sebanyak 63,33\%, sedangkan dari observer 2 sebanyak $63,33 \%$.

Pada pertemuan ke-6 siklus II yang dilaksanakan pada hari Jum'at tanggal 28 April 2017 pukul 15.00-17.00. Pelatih memberikan beberapa drill variasi latihan shooting yaitu: (1) Titan shooting drill, (2) Post shooting drill, (3) free throw line shooting. Hasilnya adalah pada sikap persiapan didapatkan hasil persentase benar peserta dari observer 1 sebanyak $90 \%$, sedangkan dari observer 2 sebanyak 90\%. Gerakan shooting didapatkan hasil persentase benar peserta dari observer 1 sebanyak $68,89 \%$, sedangkan dari observer 2 sebanyak 73,33\%. Pada gerakan lanjutan didapatkan hasil persentase benar peserta dari observer 1 sebanyak $70 \%$, sedangkan dari observer 2 sebanyak $73,33 \%$. Persentase ratarata peningkatan akurasi shooting peserta ekstrakurikuler bolabasket SMP Laboratorium UM dari sesudah siklus I dan sesudah siklus II sebesar $45,96 \%$.

Dari hasil data mengenai tingkat keberhasilan peserta ekstrakurikuler dalam melakukan latihan shooting bolabasket di SMP Laboratorium UM yang telah diperoleh dari tindakan disiklus II, maka bisa disimpulkan tujuan dari penelitian ini telah tercapai dan tidak perlu diadakan tindak lanjut pada siklus berikutnya.

\section{PEMBAHASAN}

Observasi awal yang dilaksanakan pada hari Selasa, Kamis, dan Sabtu tanggal 5, 7, dan 19 November 2016 yang dilaksanakan pukul 15.00 WIB - 17.00 WIB di lapangan bolabasket SMP Laboratorium UM dengan menggunakan lembar observasi saat latihan dan games, angket yang diberikan kepada peserta ekstrakurikuler, dan wawancara dengan pelatih, maka diperoleh data sebagai berikut: pada hari pertama dari 15 peserta yang hadir $73,33 \%$ peserta dapat melakukan teknik shooting dengan cukup baik, dan $26,67 \%$ peserta yang belum menguasai teknik shooting dengan baik. Selanjutnya pada hari kedua peneliti mengamati penggunakan teknik dasar bolabasket pada permainan 3 on 3 . Dalam game tersebut dari 53 total shooting yang dilakukan, 39,63\% dilakukan dengan benar, dan $60,37 \%$ dilakukan dengan salah. Selanjutnya pada hari ketiga peneliti mengamati penggunakan teknik dasar bolabasket pada permainan bolabasket. Dalam game tersebut dari 61 total shooting yang dilakukan, 33,33\% dilakukan dengan benar, dan $66,67 \%$ dilakukan dengan salah.

Dari data di atas, keterampilan teknik dasar shooting bolabasket yang teridentifikasi menunjukkan persentase kesalahan terbesar. Selain itu dari hasil angket yang telah diberikan kepada 20 peserta ekstrakurikuler bolabasket SMP Laboratorium UM dan wawancara dengan beberapa peserta ekstrakurikuler. Hasilnya diketahui bahwa 57,15\% peserta ekstrakurikuler memahami konsep tentang teknik dasar shooting bolabasket, tetapi $70 \%$ peserta ekstrakurikuler 
masih kesulitan dalam mempraktikkan teknik tersebut. Berdasarkan wawancara dengan pelatih, pelatih memberikan keterangan bahwa pemain masih kurang dalam hal teknik dasar khususnya shooting. Dan pelatih juga menjelaskan bahwa pada setiap pertandingan yang telah dilakukan jumlah percobaan shooting dan skor yang dihasilkan sering tidak seimbang.

Setelah ditemukan teknik shooting yang teridentifikasi kurang optimal, peneliti kembali mengobservasi teknik shooting untuk mengetahui titik kekurangan yang sebenarnya pada teknik shooting. Berpedoman pada indikator teknik shooting yang meliputi posisi awal, gerakan shooting, dan gerak lanjutan, peneliti bermaksud melakukan penelitian untuk memperbaiki keterampilan dan meningkatkan akurasi shooting peserta ekstrakurikuler bolabasket putra di SMP Laboratorium UM.

Untuk meningkatkan akurasi shooting peserta ekstrakurikuler bolabasket SMP Laboratoriun UM, peneliti menggunakan metode drill. Alasan peneliti menggunakan metode drill karena pembentukan kebiasaan menggunakan metode ini akan menambah ketepatan dan kecepatan dalam pelaksanaannya, dan gerakan-gerakan yang rumit, kompleks akan menjadi otomatis. Selain itu Fikri (2013:4), Candra (2014:145), Mahardika (2014:12), dan Susanto (2015:449) menyatakan dalam hasil penelitiannya bahwa latihan atau pembelajaran menggunakan metode drill dapat meningkatkan keterampilan olahraga secara signifikan.

Berdasarkan hasil yang diperoleh dari siklus I yang telah dilakukan, peningkatan keterampilan shooting peserta ekstrakurikuler bolabasket SMP Laboratorium UM meningkat dari sebelum di berikan tindakan. Menurut pengamatan observer 1, Pada sikap persiapan tingkat kebenaran gerakan telah ada peningkatan dari $40 \%$ menjadi $63,33 \%$. Pada gerakan shooting tingkat kebenaran gerakan telah mengalami peningkatan dari $31 \%$ menjadi $44,44 \%$. Dan pada gerakan lanjutan telah ada peningkatan yang semula $26,67 \%$ menjadi 46,67\%. Menurut pengamatan observer 2, Pada sikap persiapan tingkat kebenaran gerakan telah ada peningkatan dari $43,33 \%$ menjadi $56,67 \%$. Pada gerakan shooting tingkat kebenaran gerakan telah mengalami peningkatan dari $35,56 \%$ menjadi $40 \%$. Dan pada gerakan lanjutan telah ada peningkatan yang semula $26,67 \%$ menjadi $50 \%$. Selain itu, peningkatan hasil tes 1 dan tes 2 , persentase rata-rata peningkatan akurasi shooting peserta ekstrakurikuler bolabasket SMP Laboratorium UM sebelum diberikan perlakuan dan sesudah siklus I sebesar $25,43 \%$.
Kaitannya dengan keterampilan peserta ekstrakurikuler bolabasket SMP Laboratorium UM khususnya dalam teknik shooting memang perlu dimiliki oleh setiap atlet guna menghasilakan permainan yang maksimal. Dimana teknik shooting sangat diperlukan untuk dapat mencetak angka dalam suatu pertandingan agar dapat memperoleh kemenangan. Oleh karena itu, dengan adanya hasil penelitian ini, maka peneliti bermaksud untuk melajutkan penelitian pada siklus II untuk memperbaiki kekurangan pada siklus I.

Berdasarkan hasil yang diperoleh dari siklus II yang telah dilakukan, peningkatan keterampilan shooting peserta ekstrakurikuler bolabasket SMP Laboratorium UM meningkat dari siklus I. Menurut pengamatan observer 1, Pada sikap persiapan tingkat kebenaran gerakan telah ada peningkatan dari $53,33 \%$ menjadi $90 \%$. Pada gerakan shooting tingkat kebenaran gerakan telah mengalami peningkatan dari $37,78 \%$ menjadi $68,89 \%$. Dan pada gerakan lanjutan telah ada peningkatan yang semula $43,33 \%$ menjadi $70 \%$. Menurut pengamatan observer 2, Pada sikap persiapan tingkat kebenaran gerakan telah ada peningkatan dari $53,33 \%$ menjadi $90 \%$. Pada gerakan shooting tingkat kebenaran gerakan telah mengalami peningkatan dari $33,33 \%$ menjadi $73,33 \%$. Dan pada gerakan lanjutan telah ada peningkatan yang semula $40 \%$ menjadi $73,33 \%$. Selain itu, persentase rata-rata peningkatan akurasi shooting peserta ekstrakurikuler bolabasket SMP Laboratorium UM meningkat dari sesudah siklus I dan sesudah siklus II sebesar 45,96\%.

Berdasarkan hasil di atas dijelaskan bahwa dalam keterampilan dan akurasi shooting bolabasket peserta ekstrakurikuler SMP Laboratorium UM mengalami peningkatan dari sebelum diberi tindakan, sesudah siklus I, dan sesudah siklus II . Sehingga dapat disimpulkan bahwa cara dan penyusunan program latihan disusun secara efisien dan efektif, maka peserta ekstrakurikuler mendapat kesempatan untuk berlatih atau mendapatkan pengalaman gerak yang sebanyak-banyaknya. Dengan demikian, keterampilan dan akurasi shooting peserta ekstrakurikuler bolabasket putra SMP Laboratorium UM meningkat setelah diberikan latihan menggunakan metode drill.

\section{KESIMPULAN}

Berdasarkan hasil dari penelitian tindakan olahraga yang telah dilakukan, maka dalam pelaksanaan penelitian dengan materi 
teknik dasar shooting peserta ekstrakurikuler bolabasket putra SMP Laboratorium UM, dengan menggunakan metode drill pada siklus I dan II memberikan pengaruh terhadap peningkatan keterampilan dan akurasi shooting peserta ekstrakurikuler bolabasket putra SMP Laboratorium UM.

\section{DAFTAR PUSTAKA}

Ahmadi, N. 2007. Permainan Bola Basket. Yogyakarta: Era Intermedia.

Arikunto, S. 2010. Evaluasi Program Pendidikan: Pedoman teoritis praktis bagi mahasiswa dan praktisi mahasiswa. Jakarta: PT Bumi Aksara.

Budiwanto, Setyo. 2012. Metodologi Latihan Olahraga. Malang. Universitas Negeri Malang.

Candra, B, S. 2014. Penerapan Model Pembelajaran Drill And Practice Terhadap Hasil Belajar Chest Pass Pada Pemainan Bola Basket (Studi Pada Siswa Kelas X Sma Negeri 1 Kota Mojokerto). Jurnal Pendidikan Olahraga dan/Kesehatan. (online). 02 (01): 141-145, (http: Yejournal. unesa.ac.id /index.php/jurnal-pendidikanjasmani/issue/ (archive), diakses 13 Februari 2017.

FIBA. 2014. Official Basketball Rules. Puerto Rico, San Juan: FIBA Central Board.

Fikri, M, D. 2013. Pengaruh Pelatihan 3-Point 5Post Drill's Terhadap Hasil 3-Point Shooting Pada Club Bolabasket Putra Sma Negeri 1 Taman. Jurnal Ilmu Keolahragaan. (online). 01 (02): 1-7, (http://www. ejournal. unesa.ac.id/index.php/jurnal-kesehatanolahraga/article/ view/2359), diakses 13 Februari 2017.

Hamalik, Oemar. 2012. Kurikulum dan Pembelajaran. Jakarta: Bumi Aksara.

Hapsari, U.R. Widodo, P, B. Setyawan, I. 2010. Hubungan Antara Minat Mengikuti Kegiatan Ekstrakurikuler dengan Intensi Delinkuensi Remaja Pada Siswa Sekolah Menengah Kejuruan (SMK) di Kota Semarang, (online) (http://www.undip.ac.id), diakses 10 Desember 2016.

Harmono, 2014. Kontribusi Konsentrasi Terhadap Ketepatan Pukulan Jumping Smash Pada Bulutangkis. Jurnal Kesehatan Olahraga. (online). 06

(02):274-282 (ejournal.unesa.ac.id/article/8763/66/articl e.pdf), diakses 15 Januari 2017.

Harsono. 2015. Kepelatihan Olahraga. Bandung: PT REMAJA ROSDAKARYA.

Kurniawan, N, A. 2014. Hubungan Antara Tingkat Konsentrasi Siswa Dengan Ketepatan Free Throw Dalam Permainan Bola Basket. Jurnal Pendidikan Olahraga dan Kesehatan. (online). 02 (10):249-252, (http://ejournal.unesa.ac.id/index.php/jurn al-pendidikan-jasmani/issue/archive), diakses 11 Desember 2016.

Kusumawati, M. 2014. Penelitian Pendidikan Penjasorkes. Bandung: Alfabeta.

Mahardika, W. 2014. Perbedaan Pengaruh Pendekatan Pembelajaran Praktik Drill Dan Bermain Terhadap Hasil Jump Shoot Bolabasket. Jurnal Ilmiah SPIRIT, ISSN. (online). 01 (02): 1-7, (https://ejournal. unesa.ac.id/index.php/Jurnal-IlmiahPIRIT-ISSN/article/view /2360), diakses 13 Februari 2017.

Mu'arifin. 2012. Dasar-dasar Pendidikan Jasmani dan Olahraga. Malang: Universitas Negeri Malang (UM PRESS).

Oliver, J. 2007. Dasar-dasar Bolabasket. Bandung: PT Intan Sejati

(online). (http://id.wikipedia.org/wiki/ Bola basket), diakses tanggal 2 Desember 2016.

Peraturan Menteri Pendidikan dan Kebudayaan Republik Indonesia Nomor 62 tahun 2014 tentang Kegiatan Ekstrakurikuler Pada Pendidikan Dasar Dan Pendidikan Menengah. (online) (http://abkin.org/download/lampiran-iiipedoman-kegiatan -ekstrakurikuler.pdff, diakses 10 Desember2016.

Podmenik, N. Leskosek, B. \& Erculj, F. The Effect of Introducing a Smaller and Lighter Basketball on Female Basketball Players' Shot Accuracy. 2012. International Journal of Human Kinetics, (online). 31 (1): 131-137, (https://www.ncbi.nlm.nih.gov/pmc/article s/PMC3588654/), diakses 12 Februari 2017.

Sagala, S. 2009. Konsep dan Makna Pembelajaran. Bandung: ALFABETA.

Setiawan, R. 2014. Kontribusi Kekuatan Otot Tungkai Dan Keseimbangan Terhadap Kemampuan Akurasi Tendangan. Jurnal Kesehatan Olahraga.(online). 06 
(02):274-282 (http://ejournal.unesa.ac.id /index.php/jurnal-kesehatan-

olahraga/article/view/17383. pdf), diakses 15 Januari 2017.

Sudijono, S. 2010. Pengantar Statistik Pendidikan. Jakarta: PT Rajagrafindo Persada.

Sukma, E, T. Supriatna, E. Atiq, A. 2013. Upaya Peningkatan Keterampilan Teknik Dasar Basket Melalui Variasi Latihan Siswa Ekstrakurikuler SMAN 1 Sintang, (Online), (http://www.untan.ac.id), diakses 2 Desember 2016.

Susana, A \& Wibowo, S. 2013. Penggunakan Media Pelatihan Bola Modifikasi Terhadap Hasil Sepaksila Pada Ekstrakurikuler Sepak Takraw. Jurnal Pendidikan Olahraga dan Kesehatan. (online). 1 (1): 137143,(http: / / ejournal.unesa. ac.id/article/4878/68/article. pdf), diakses 11 Desember 2016.

Susanto, T, A, A. 2015. Perbedaan Metode Latihan (Drill) Dan Metode Bermain Terhadap Hasil Belajar Passing Dalam Permainan Futsal Pada Peserta Ekstrakurikuler di Smk Negeri 1 Lamongan Dan Smk Negeri 2 Lamongan. Jurnal Pendidikan Olahraga dan Kesehatan. (online). 03 (02): 443-449, (http://www.ejournal. unesa.ac.id/article/17600/68/ article.pdf), diakses 13 Februari 2017.

Trianto. 2010. Panduan_Lengkap Penelitian Tindakan Kelas. Jakarta: Buku Berkualitas Prima.

Umashankara, R. Ravi, T. \& siddappaswamy, G. Sport Training: Aeorobic as a part of Training With Different Duration and Frequensy to Improve selected Functional Qualities. 2014. International Journal of Health, Physical Education and Computer Science in Sport, (online). 15 (1): 453-455, (http: / /www. Ijhpecss.org/internationaljournal15.pdf), diakses 15 Desember 2016.

Universitas Negeri Malang. 2010. Pedoman Penulisan Karya Ilmiah. Malang: Universitas Negeri Malang (UM Press).

Winarno. 2013. Metodologi Penelitian dalam Pendidikan Jasmani. Malang: Universitas Negeri Malang (UM Press).

Wissel, H. 2000. Bola Basket. Terjemahan.Bagus P. Jakarta: PT Raja Grafindo Persada.

Zhen, L. Wang, L. \& Hao, Z. A Biomechanical Analysis of Basketball Shooting. 2013.
International Journal of Simulation Systems Science Technology, (online). 10 (1): 1-5, (http://www. ijsst.info/Vol-16/TIL/No3B/paper1.pdf), diakses 12 Februari 2017. 